\title{
Analysis of the Factors Influencing Japan's Soybean Import Trade: Based on Gravity Model
}

\author{
Jiayou Wang \\ College of Economics and Management, China Agricultural University, Beijing, China \\ Email: jiayou1214@163.com
}

Received 26 January 2016; accepted 19 February 2016; published 22 February 2016

Copyright (C) 2016 by author and Scientific Research Publishing Inc.

This work is licensed under the Creative Commons Attribution International License (CC BY). http://creativecommons.org/licenses/by/4.0/

(c) (i) Open Access

\begin{abstract}
Since 2004, Japan's soybean import has been reduced gradually. In order to analyze this phenomenon, this article introduces situation of Japan's soybean production and import, on the basis of qualitative analysis of factors influencing soybean import trade, and uses the gravity model for quantitative evaluation of the main factors influencing Japan's soybean import trade.
\end{abstract}

\section{Keywords}

\section{Soybean Import, Gravity Model, Japan}

\section{Introduction}

Since the 1960 s, with the high-speed development of Japan's economy, the national per capita income level increases continuously; great changes have been taken place in people's diet structure; and the demand for oil products is increasing. As a result, the demand for soybean which is a raw material of edible oil has grown significantly. Due to the limited domestic soybean yield, Japan has to import a large number of soybeans in order to meet domestic consumption demand; therefore, Japan's soybean imports have been rising nearly 40 years. But after the 21st century, especially after 2004, the soybean import began to decrease significantly.

Research about this phenomenon is limited. According to the existing research from previous scholars, there is a majority of descriptive analysis and prediction about Japan's soybean import, and few study on exploring its deep reasons. Tao Yu (2004) predicted that Japan's soybean import may be declined in 2004; the reason was that soaring of the future price in CBOT led to domestic crushing profit loss. Liu and Shen (2006) thought that Japan's domestic support policy which encourages their own farmers to plant soybean and other oil crops and uses border measures to protect domestic oil processing industry has greatly reduced the import of vegetable oil 
[1]. According to Japan's current situation, the soybean production of their own is less than 300 thousand tons, and the demand for food processing is 1 million tons. In addition, with the increasing of feed and industrial raw materials, Japan imported a large number of soybeans every year. Xie (2007) analyzed that Japan's domestic demand for soybean has a tendency of continuously expanding [2].

This article qualitatively analyzes the key factors influencing Japan's soybean import, mainly researches the main reasons for decline in soybean import in Japan through trade gravity model, and presents empirical results and conclusion.

\section{Situation of Japan's Soybean Production and Import}

The residents in Japan have always been used to eating soy foods, and soybean cultivation has a long history in there. However, Japan's land area is narrow, soybean cultivated area is small, so Japan's soybean production is low; the domestic production of soybean cannot satisfy the consumer demand far away. So, Japan is one of the biggest importers of soybeans in the world.

Figure 1 shows that since 1995, Japan's soybean production has been hovering 100 to 300 thousand tons and in recent years, it began to show a downward trend. Soybean consumption began to decline since 2003, and soybean consumption in 2011 is almost half as much as in 2002. The trends of soybean import and consumption are consistent, which have showed a downward trend since 2004.

Table 1 shows that Japan imports soybean mainly from the United States, Brazil, Canada and China. Except in 2011, Japan's soybean import from these four countries is more than $99 \%$ of the total import. Among them, the share of import from the United States and China is showing a tendency of decrease, while the share of import from Brazil and Canada presents a rising trend.

\section{Influencing Factors Analysis on Japan’s Soybean Import Trade}

\subsection{Domestic Factors Influencing Japan's Soybean Import}

\subsubsection{Change of Japan's Domestic Soybean Demand}

The demand for oil production has increased dramatically from the 1960s as the Japan's diet shifted more toward Western style cuisines that depend on heavier oil use. Therefore, the demand for soybean which is a main raw material of edible oil enhanced unceasingly. But after 2004, demand for soybeans declined in domestic because of rising prices of soybean oil and other raw materials in the international market, the volume used in foods reached a low of less than one million tons for the first time in 2009, at the same time, the recent poor economic condition also made the soybean consumption decreased. Therefore, soybean consumption will be introduced to the gravity model, at the same time; the descent rate of domestic soybean demand is influenced directly by the domestic economic development speed and population growth speed, so the domestic population and GDP will also be introduced to reflect the domestic demand of soybean.

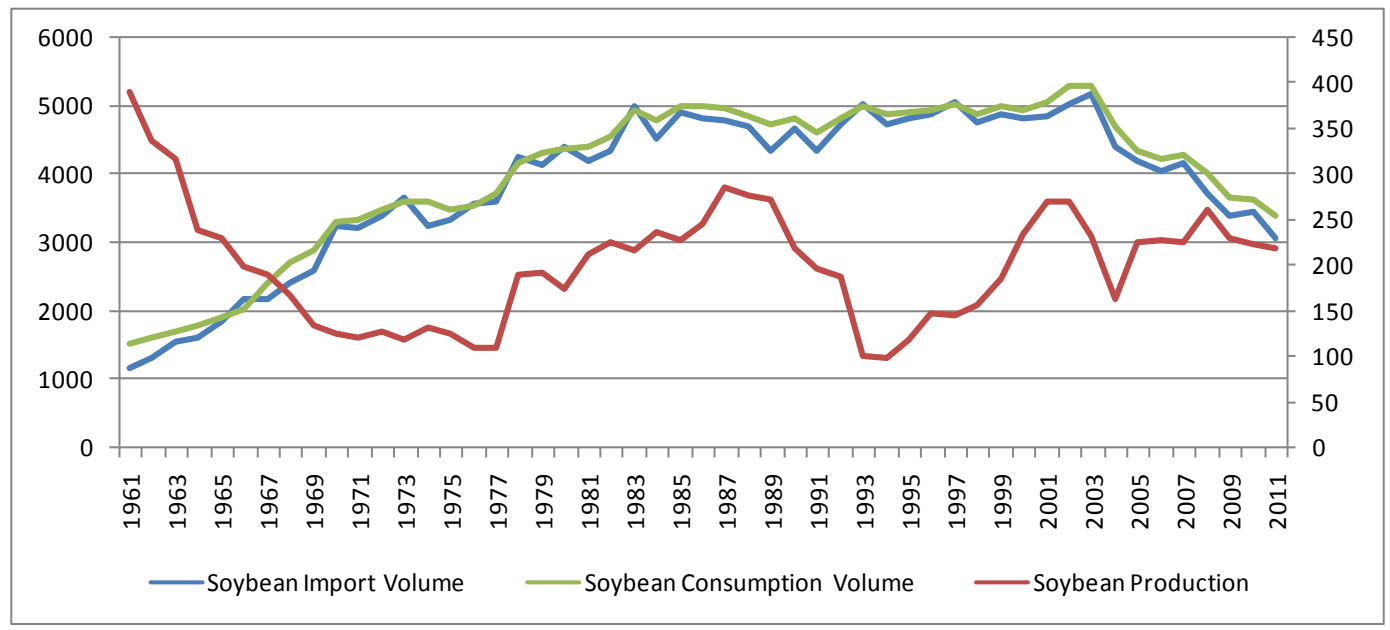

Figure 1. Japan’s soybean production, consumption and import volume from 1995 to 2011 (Unit: 1000 MT). 
Table 1. Situation of Japan’s soybean import source (Unit: \%).

\begin{tabular}{cccccc}
\hline Year & US & Brazil & Canada & China & Total proportion the four \\
\hline 2005 & 74.78 & 13.46 & 7.30 & 4.40 & 99.94 \\
2006 & 79.78 & 9.34 & 6.97 & 3.87 & 99.96 \\
2007 & 79.91 & 8.82 & 7.34 & 3.29 & 99.45 \\
2008 & 73.54 & 15.31 & 8.76 & 2.32 & 99.92 \\
2009 & 71.15 & 16.81 & 10.41 & 1.50 & 99.88 \\
2010 & 71.39 & 16.44 & 10.74 & 1.39 & 99.95 \\
2011 & 62.12 & 17.48 & 11.64 & 1.44 & 92.69 \\
\hline
\end{tabular}

Source: Calculated by data from MAFF.

\subsubsection{Change of Japan's Domestic Soybean Supply}

Although the history of Japan's soybean production is very long, in the past 30 years, domestic soybean production accounts for only $3 \%-5 \%$ of the soybean supply. In recent years, domestic soybean production is declining, in 2011, domestic soybean production is 219,900 tons, declined one percent from a year earlier, only accounts for $23 \%$ of the soy food consumption, there is a close relationship between this development situation and domestic supply. Due to the low comparative advantage of soybean, farmers tend to replant other crops which have high economic benefit, the cultivated area of soybean has declined each year since 2008, and the yield of soybean presents the downward fluctuant trend at the same time. In addition, the stocks of soybean can be used to smooth the gap between domestic supply and demand, in recent years; Japan's stocks of soybean presents the downward fluctuant trend. Therefore, this article will introduce the harvested area of soybean and stocks of soybean which on behalf of the Japan's domestic soybean supply in the gravity model.

\subsubsection{Change of Japan's Soybean Industry Policy}

Japan's soybean industry policy mainly includes the soybean payment plan which started in 1998 and canceled in 2000. Soybean Deficiency Payments was replaced by Direct Subsidies in 2000. In 2001, the Japanese government increased an incentive fund of 100 thousand yen per hectare to stimulate farmers to grow soybeans. MAFF has announced targets for domestic agricultural production through 2020, with the goal of soybean production levels reaching 17 percent of total demand, which calls for breeding and cultivation of high yield varieties and improvement of cultivation techniques for soybeans. To a certain extent, these policies can bring positive impact on the development of soybean industry in Japan, at the same time; they will be reflected in the domestic soybean supply, so in the gravity model will not introduce corresponding policy variables.

\subsubsection{Change of Japan's Soybean Trade Policy}

Tariff measures have a direct effect on soybean trade in Japan. The tariff on soybean import is zero in Japan but tariff measure on soybean oil import is much tighter. The measure is aimed to protect domestic oil processing enterprise. While considering the soybean imported mainly as a raw production material of edible oil, soybean oil import has a substitution relationship with soybean import. Therefore, soybean oil import volume will be introduced in the gravity model to reflect its influence on soybean import.

Non-tariff trade barrier also has a direct effect on Japan's import. In April 2001, MAFF officially enacted the law of labeling of GM food, made the specific identification method for soybean which has passed safety certification and other four kinds of GM agricultural products. In September 2001, MAFF announced that high oleic acid soybean and its processing products would be added into the law, and requested that the species of specified food and its processing products should be revised every year. This article will introduce a virtual variable which is whether imposing controls on genetically modified products into the gravity model and evaluate its impact on Japan's soybean import.

\subsection{International Factors Influencing Japan's Soybean Import}

The main factor of Japan's soybean import is the price differential between Japan and the soybean exporter. On 
the demand side, the factors which affect the consumption and export includes the population of soybean exporter, economic development level and export prices; on the supply side, the factors which affect the export quantity and price includes soybean production of exporter, soybean stock and production costs.

\subsubsection{Soybean Export Prices of Leading Exporters}

Table 2 shows that in the past few years, the price of domestic soybean producers in Japan has been significantly higher than the main exporter's. Therefore, if the soybean quality difference between at home and abroad is small, the larger the price gaps, the greater incentive to domestic soybean import.

\subsubsection{Yield of Soybean at Home and Abroad}

Because Japan's soybean of domestic production are low yield non-GM soybeans, and other major soybean producing countries are mainly planting high yield GM soybeans, it makes the yield of soybean in Japan is lower than the major soybean producing countries (Table 3). It also reflects that the cost of Japan's soybean production is higher, and Japan's soybean planting area is not large and is very limited, according to Japan's domestic high demand for soybeans, the incentive of soybean import is very large.

\section{Analysis of the Factors Influencing Japan's Soybean Import Trade Based on Gravity Model}

This paper chooses the gravity model as a tool which is applied comparative mature internationally, to identify important influencing factors on Japan's soybean trade, and quantitative evaluate the effect size. The reason why choose the model is considering the following factors: firstly, the expected transportation distance is likely to be an important factor influencing Japan's soybean imports; second, the gravity model is very suitable for empirical research on the bilateral trade relations involving multiple countries; finally, the gravity model is easy to expand, which includes the special factors affecting Japan's soybean import.

\subsection{The Basic Theory of the Gravity Model}

The gravity model is named because of its equation similar to Newton's gravity equation, it shows the trade flow between two countries is proportional to their economy scale, and is inversely proportional to the distance between them. The first one who put gravity model to analysis of international trade are Tinbergen (1962) and

Table 2. Leading exporters' soybean export prices and price of domestic soybean producers in Japan (Unit: USD/MT).

\begin{tabular}{cccccccc}
\hline Country & 2005 & 2006 & 2007 & 2008 & 2009 & 2010 \\
\hline US & 246 & 246 & 336 & 457 & 407 & 439 \\
Canada & 283 & 289 & 339 & 463 & 424 & 493 \\
Brazil & 227 & 238 & 283 & 447 & 400 & 427 \\
China & 452 & 512 & 644 & 811 & 748 & 835 \\
Japan & 2803 & 2072 & 1813 & 1539 & 1651 & 1468 \\
Higher than the average four & $828 \%$ & $544 \%$ & $352 \%$ & $182 \%$ & $233 \%$ & $167 \%$ \\
\hline
\end{tabular}

Table 3. Yield comparison between leading exporters and Japan (Unit: Kg/ha).

\begin{tabular}{|c|c|c|c|c|c|c|}
\hline Country & 2005 & 2006 & 2007 & 2008 & 2009 & 2010 \\
\hline US & 2896 & 2881 & 2806 & 2671 & 2957 & 2922 \\
\hline Canada & 2708 & 2885 & 2301 & 2790 & 2535 & 2942 \\
\hline Brazil & 2230 & 2379 & 2813 & 2816 & 2636 & 2947 \\
\hline China & 1704 & 1665 & 1453 & 1702 & 1630 & 1771 \\
\hline Japan & 1679 & 1612 & 1639 & 1779 & 1581 & 1615 \\
\hline
\end{tabular}


Pullianen (1963), soon Linenmann (1969) introduced the population variable into this model [3]-[5]. Then the gravity model is evolved, but a few basic variables are fixed, the general equation can be summarized as follows:

$$
\ln X_{\mathrm{ijt}}=\alpha+\beta_{1} \ln \mathrm{GDP}_{\mathrm{it}}+\beta_{2} \ln \mathrm{GDP}_{\mathrm{jt}}+\beta_{3} \ln \mathrm{POP}_{\mathrm{it}}+\beta_{4} \ln \mathrm{POP}_{\mathrm{jt}}+\beta_{5} \ln D_{\mathrm{ijt}}+\mu_{\mathrm{ijt}}
$$

Among them, $X$ represents the bilateral trade flow (amount); GDP represents trading nation's gross domestic product; POP represents population of trading nation; $D$ represents the distance between the trading nations; $i$ represents the exporter, $j$ represents the importer, $t$ represents the time; $\alpha, \beta$ and $\mu$, perceptively represent the constants, the slope item and the random error term.

\subsection{The Construction of Model and Theoretical Hypothesis}

According to the characteristics of the Japan's soybean import trade, it introduces some new explanatory variables. Specific process is as follows: 1) this paper uses GDP, domestic population and soybean consumption to respectively reflect the macroeconomic situation, the influence of the demand for soybean to import. 2) To a great extent, soybean harvest area can explain the soybean industry policy impact on soybean supply, and to a certain extent, stocks can explain the fluctuant situation of import. So the two variables will be introduced to test their effect on soybean import. 3) According to the traditional economics theory, the price has a significant influence on trade quantity and share, so they will be introduced into the model. At the same time, the change of exchange rate will affect both sides of the relative prices, it will be also introduced. 4) According to the actual situation of Japan, $70 \%-80 \%$ of soybean import is used as the material of the domestic crushing industry, the domestic crushing industry could not produce enough soybean oil to meet the need the demand of Japan generally, it needs to import soybean oil to equivalent the need of domestic demand, so there is a substitute relationship between soybean oil import and soybean import, this paper introduces soybean oil import volume to analyze its effect on Japan's soybean import volume. 5) There are some policy factors and sudden factors which are hard to quantify, impact on Japan's import. Therefore, they will be introduced into the model by taking the form of virtual variables. The model mainly includes two virtual variables: 1) Japan's GM soybean identifying policy, it will be set to 0 before the policy and come to 1 after the policy; 2) the 2008 financial crisis, the virtual variable will be set to 0 before the financial crisis, come to 1 after the crisis.

According to the set variables above, the gravity model expression of Japan's import trade is as follows:

$$
\begin{aligned}
\ln X_{i j t}= & \alpha+\beta_{1} \ln \mathrm{GDP}_{i t}+\beta_{2} \ln \mathrm{GDP}_{j t}+\beta_{3} \ln \mathrm{POP}_{i t}+\beta_{4} \ln \mathrm{POP}_{j t}+\beta_{5} \ln \mathrm{D}_{i j t}+\beta_{6} \ln \mathrm{P}_{i j t} \\
& +\beta_{7} \ln \mathrm{RATE}_{i j t}+\beta_{8} \ln \mathrm{POR}_{i t}+\beta_{9} \ln \mathrm{STO}_{i t}+\beta_{10} \ln \mathrm{STO}_{j t}+\beta_{11} \ln \mathrm{CON}_{j t} \\
& +\beta_{12} \ln \mathrm{LAND}_{j t}+\beta_{13} \ln \mathrm{OIL}_{j t}+\beta_{14} \mathrm{~T}+\beta_{15} \mathrm{~F}+\mu_{i j t}
\end{aligned}
$$

In the expression, $i$ represents the nations export soybean to Japan, $j$ represents Japan, $t$ represents the time; $X_{i j t}$ represents Japan's soybean import volume from trading partners; $\alpha$ and $\beta$ represent coefficient to be estimated, which $\alpha$ is a constant, $\beta_{1}-\beta_{15}$ reflect the corresponding variables impact on Japan's soybean import. Table 4 lists the implication of various explanatory variables, expected symbols and theoretical assumptions.

\subsection{Selection and Source of Data}

This article selects panel data from 1995 to 2011, according to Japan's soybean import sources, source of imports includes the US, Brazil, Canada and China, which can fully reflect the Japan's pattern of soybean import.

The data used in the trade gravity model mainly include: 1) the population and GDP of Japan's source of imports from 1995 to 2011; 2) the population and GDP of Japan from 1995 to 2011; 3) the bilateral exchange rate between yen and money of soybean's source of imports from 1995 to 2011; 4) the linear distance from Tokyo respectively to New York, Brasilia, Ottawa and Beijing; 5) Japan's soybean import volume and amount by country from 1995 to 2011; 6) soybean production and stocks of source of imports from 1995 to 2011; 7) Japan's soybean consumption and stocks from 1995 to 2011; 8) Japan's soybean oil import volume from 1995 to 2011; 9) Japan's soybean harvested area from 1995 to 2011.

The data of Japan and its soybean source of imports of population, GDP, the bilateral exchange rate between yen and money of soybean's source of imports are from world bank database; the data of the linear distance from Tokyo respectively to New York, Brasilia, Ottawa and Beijing are from Baidu Map; the data of Japan's 
Table 4. Implication of variables, expected symbol and theoretical assumptions.

\begin{tabular}{|c|c|c|c|}
\hline Variables & Implication & $\begin{array}{l}\text { Expected } \\
\text { Symbol }\end{array}$ & Theoretical Assumptions \\
\hline $\mathrm{GDP}_{i t}$ & GDP of Japan's source of import & + & $\begin{array}{l}\text { It reflects soybean export supply ability of source of imports, } \\
\text { the greater the amount of economic scale, the greater the } \\
\text { potential ability to export, the greater the Japan's soybean import }\end{array}$ \\
\hline $\mathrm{GDP}_{j t}$ & Japan’s GDP & + & $\begin{array}{l}\text { It reflects the Japan's soybean import demand, the greater the } \\
\text { amount of economic scale, the greater the potential ability to } \\
\text { import, the greater the soybean import }\end{array}$ \\
\hline $\mathrm{POP}_{i t}$ & Population of Japan's source of import & - & $\begin{array}{l}\text { The more a country's population, the larger the domestic market } \\
\text { scale, the less need to rely on the international market, and } \\
\text { smaller export scale, the smaller Japan's soybean import }\end{array}$ \\
\hline $\mathrm{POP}_{j t}$ & Population of Japan & + & $\begin{array}{l}\text { It reflects the Japan's soybean import demand, the more } \\
\text { population, the greater the demand, the greater the import }\end{array}$ \\
\hline$D_{i j t}$ & $\begin{array}{l}\text { The linear distance from Tokyo to capital } \\
\text { or economic center of source of import }\end{array}$ & - & $\begin{array}{l}\text { The farther the distance, the greater the cost of transportation, } \\
\text { the smaller the import }\end{array}$ \\
\hline $\mathrm{P}_{i j t}$ & $\begin{array}{l}\text { The soybean import price from } \\
\text { Japan's source of import }\end{array}$ & - & $\begin{array}{l}\text { It reflects the supply ability of soybean source of imports, import } \\
\text { price rises, Japan will reduce soybean import from the country }\end{array}$ \\
\hline $\operatorname{RATE}_{i j t}$ & $\begin{array}{l}\text { The exchange rate of source of } \\
\text { imports currency against yen }\end{array}$ & + & $\begin{array}{l}\text { It reflects the influence on Japan's soybean import by bilateral } \\
\text { exchange rate, the decrease of exchange rate means that Japan } \\
\text { will pay a higher price, it will cause soybean import reduced }\end{array}$ \\
\hline $\mathrm{POR}_{i t}$ & $\begin{array}{l}\text { Annual soybean production of } \\
\text { source of import }\end{array}$ & + & $\begin{array}{l}\text { It reflects the soybean supply ability of the source of imports, } \\
\text { the higher the annual output, the stronger the soybean supply } \\
\text { ability, the greater Japan's import }\end{array}$ \\
\hline $\mathrm{CON}_{j t}$ & Japan's annual soybean consumption & + & $\begin{array}{l}\text { It reflects the Japan's soybean demand, the greater the annual } \\
\text { consumption, the greater the demand for soybean import }\end{array}$ \\
\hline $\mathrm{STO}_{i t}$ & Soybean stocks of source of import & - & $\begin{array}{l}\text { It reflects the soybean supply ability of source of imports, while } \\
\text { domestic consumption remains the same, the more stocks shows } \\
\text { the less potential exports, the less Japan's import }\end{array}$ \\
\hline $\mathrm{STO}_{j t}$ & Japan's soybean stocks & - & $\begin{array}{l}\text { It reflects the Japan's soybean demand, when consumption remains } \\
\text { the same, the more the stocks, the less soybean import need }\end{array}$ \\
\hline $\mathrm{LAND}_{j t}$ & Japan's soybean harvested area & - & $\begin{array}{l}\text { It reflects the Japan's soybean supply ability, the bigger the harvested } \\
\text { area, the stronger the self-sufficiency, the less the import }\end{array}$ \\
\hline $\mathrm{OIL}_{j t}$ & Japan’s soybean oil import volume & - & $\begin{array}{l}\text { It reflects the substitution effect of soybean oil import on soybean } \\
\text { import, the more soybean oil import, the less soybean import }\end{array}$ \\
\hline $\mathrm{T}$ & $\begin{array}{l}\text { Virtual variable of Japan's implementation } \\
\text { of the policy to labeling of GM food }\end{array}$ & - & $\begin{array}{l}\text { After implementation to labeling of GM food, because the } \\
\text { consumer awareness of GM, soybean import decreases }\end{array}$ \\
\hline $\mathrm{F}$ & Virtual variable of the 2008 financial crisis & - & $\begin{array}{l}\text { After the outbreak of the financial crisis, the global economic } \\
\text { recession began, Japan's demand and source of imports supply } \\
\text { capacity both decreased, soybean import decreased }\end{array}$ \\
\hline
\end{tabular}

soybean import volume and amount by country are from the MAFF database; the data of soybean production and stocks of source of imports, Japan's soybean oil import volume and Japan's soybean harvested area are from the FAO database and the USDA database.

\subsection{Estimation and Correction of the Model}

Using the Eviews6.0 to estimate the model by OLS, the results are as follows:

$$
\begin{aligned}
& \ln X_{i j t}=-65.28+0.05 \ln \mathrm{GDP}_{i t}+2.18 \ln \mathrm{GDP}_{j t}-0.56 \ln \mathrm{POP}_{i t}+1.48 \ln \mathrm{POP}_{j t}-0.87 \ln \mathrm{D}_{i j t} \\
&-0.09 \ln \mathrm{P}_{i j t}+0.93 \ln \mathrm{RATE}_{i j t}+1.24 \ln \mathrm{POR}_{i t}-0.11 \ln \mathrm{STO}_{i t}-0.02 \ln \mathrm{STO}_{j t} \\
&+2.05 \ln \mathrm{CON}_{j t}+0.53 \ln \mathrm{LAND}_{j t}-0.1 \ln \mathrm{OIL}_{j t}+0.1 \mathrm{~T}-0.26 \mathrm{~F} \\
& R^{2}=0.926 \mathrm{~F}=43.6 \mathrm{DW}=0.64
\end{aligned}
$$

We can understand from the estimating result, the fitting degree of the whole model is higher, but a part of 
single explanatory variables are not significant, estimated symbol is in contrast to the expected symbol. The variables which pass the significance test and estimate symbol is consistent with the expected symbol are RATE $E_{i j t}$, $\mathrm{POR}_{i t}, \mathrm{STO}_{i t}$ and $\mathrm{CON}_{j t}$. So I will choose the four explanatory variables as the basic explanatory variables, and add some other variables to the model to see the fitting effect, and observe their significance and consistency of symbols and the expected. After several attempts, a revised model is:

$$
\begin{aligned}
\ln \mathrm{X}_{i j t}= & \alpha+\beta_{1} \ln \mathrm{GDP}_{i t}+\beta_{2} \ln \mathrm{D}_{i j t} \beta_{3} \ln \mathrm{RATE}_{i j t}+\beta_{4} \ln \mathrm{POR}_{i t}+\beta_{5} \ln \mathrm{STO}_{i t} \\
& +\beta_{6} \ln \mathrm{CON}_{j t}+\beta_{7} \ln \mathrm{OIL}_{j \mathrm{t}}+\beta_{8} \mathrm{~T}+\mu_{i j t}
\end{aligned}
$$

The results of the model estimation are as Table 5 shows.

As we can see from estimated results, in the revised model, the symbol of explanatory variables coefficient is basically consistent with the expected, and they are at a higher level of significance. $\mathrm{R}^{2}$ is 0.92 , which indicates that the fitting degree of model is high. The value of $\mathrm{F}$ is 84.5 , which can reject the null hypothesis in the $5 \%$ significance level. Explanatory variables are with expectations and pass the test of significance except $\mathrm{T}$, whose symbol of coefficient is not consistent and with expected. Variable $\mathrm{GDP}_{j t}, \mathrm{POP}_{i t}, \mathrm{POP}_{j}, \mathrm{P}_{i j t}, \mathrm{STO}_{j t}, \mathrm{LAND}_{j t}$ and $\mathrm{F}$ are not included in the model.

Now we will analyze the estimated results: 1) the coefficient of Japan's GDP is 2.09 and it passes the statistical test which is under 5\% significance level. It shows that 1\% growth of GDP, 2.09\% increase of Japan's soybean import. 2) The coefficient of distance variable is 0.35 and it is statistically significant, but the value is relatively small. The cause of this situation might be that $70 \%-80 \%$ soybean Japan import are used for processing soybean oil, the edible part is small, and the main raw materials of processing soybean oil are imported from the United States, Brazil and Canada, which produce GM soybean with high oil content, the edible part is imported non-GM soybean from China. So it imports more from the region which transportation cost is much more. 3) The coefficient of bilateral exchange rate between yen and money of soybean's source of imports is 1.24 , and the significance level is very high. This suggests that the bilateral exchange rate fell by $1 \%$, soybean import volume will decrease by $1.24 \%$. Exchange rate level is a sensitive factor which influences Japan's soybean import. 4) The coefficient of soybean production of source of imports is 0.87 ; its symbol is consistent with the expected and its level of significance is very high, it shows that the output of source of imports increases by $1 \%$, Japan's import will increase by $0.87 \%$. 5) The coefficient of soybean stock of source of imports is -0.12 , it's statistically significant and has a smaller value, which shows it increases by $1 \%$, Japan's soybean import will reduce by $0.12 \%$. This shows that stock of source of imports can influence Japan's soybean imports under the condition of affecting its domestic exports but the impact is not great. 6) The coefficient of Japan's soybean consumption is 2.51; its symbol is consistent with the expected and passes the test of significance. The variable has a larger impact on Japan's soybean import; domestic consumption of soybean increases by 1\%, import will increase by $2.51 \%$. It shows that the domestic consumption is an important factor affects Japan's soybean import trade. To a great extent, the explanation of Japan's import reduce is reduction of domestic consumption in recent years. 7) The coefficient of Japan's imports of soybean oil is negative; its symbol is consistent with the expected and passes the test of significance. It means that every $1 \%$ increase in soybean oil imports in Japan, soybean

Table 5. Regression results of the gravity model.

\begin{tabular}{cccc}
\hline Variables & Expected Symbol & Coefficient & T-Values \\
\hline $\ln \left(\mathrm{GDP}_{j t}\right)$ & + & 2.09 & 2.24 \\
$\ln \left(\mathrm{D}_{i j t}\right)$ & - & -0.35 & -2.91 \\
$\ln \left(\mathrm{RATE}_{i j t}\right)$ & + & 1.24 & 10.17 \\
$\ln \left(\mathrm{POR}_{i t}\right)$ & + & 0.87 & 13.92 \\
$\ln \left(\mathrm{STO}_{i t}\right)$ & - & -0.12 & -2.47 \\
$\ln \left(\mathrm{CON}_{j t}\right)$ & + & 2.51 & 4.21 \\
$\ln \left(\mathrm{OIL}_{j t}\right)$ & - & -0.11 & -2.00 \\
$\mathrm{~T}$ & - & 0.36 & 2.06 \\
\hline
\end{tabular}


import will be reduced by $0.11 \%$. The substitute relationship does exist, but substitute effect is not obvious. The statistics from USDA show that tropical vegetable oil import increases gradually in recent years, which has become Japan's second-largest main vegetable oil supply and exceeds domestic soybean oil production in 2007; as a result, its import could weaken the substitution effect of soybean oil to soybean. 8) The coefficient of Japan's labeling of GM food passed the test of significance, but its influence direction on soybean import is positive, not in conformity with expected. This situation shows that although the Japan's consumers always adhere of nonGM soybean, but its demand of GM soybean import far exceeds the non-GM soybean demand, thus the attitude of inhibiting the GM food cannot effectively restrict importing GM soybean.

\section{Main Conclusions}

This article is based on the qualitative analysis of impact factors of Japan's soybean import trade, and quantitatively analyzes the impact on Japan's soybean influenced by bilateral trader's economic scales, population, distance, price and exchange rate by using the gravity model. Results show that from domestic demand, along with Japan's economic growth slowing in recent years as well as domestic consumption reducing, soybean import will also have a certain degree of decline; in terms of domestic trade policy, Japan's soybean oil import will have a faintly substitution effect on soybean import; implementation of the policy to labeling of GM food has no obvious inhibitory effect on soybean import.

From the point of view of source of import, with the gradually reduced output of the United States and other major soybean producing countries in recent years, to some extent, it leads to a decline in Japan's soybean import in recent year; the stocks change of source of imports is more inconsistent, because its impact degree on Japan's soybean import is small, and it does not make the discussion; in addition, the yen continues to go on the foreign exchange market in recent years, which has a positive effect on Japan’s soybean import trade.

\section{References}

[1] Liu, X. and Shen, Q. (2006) Oilseed Developing Policies in Japan and Its Enlightenment to China. International Business, 2, 41-44.

[2] Xie, F. (2007) Survey of Status and History on Japanese Soybean. Soybean Bulletin, 6, 45-47.

[3] Tinbergen, J. (1962) Shaping the World Economy: Suggestions for an International Economic Policy. Twentieth Century Fund, New York.

[4] Pullianen, K.A. (1963) World Trade Study: An Econometric Model of the Patterns of the Commodity Flows in International Trade 1948-1960. Economiska Samfundets Tidskrift, 2, 78-91.

[5] Linnemann, H. (1969) Trade Flows and Geographical Distance, or the Importance of Being Neighbors. In: Bos, H.C., Ed., Towards Balanced International Growth: Essays Presented to J. Tinbergen, North-Holland, Amsterdam, 111-128. 